\title{
Work Values of Turkish and American University Students
}

\section{Zahide Karakitapoğlu Aygün Mahmut Arslan Salih Güney}

ABSTRACT. The first aim of this paper was to investigate how the traditional Protestant work ethic (PWE) and more contemporary work values (i.e., masculine, feminine, and entrepreneurship values) were related to one another, and differed across genders and two cultural contexts, namely Turkey and the U.S. The second aim was to elucidate the role of religiosity in PWE among the two cultural groups. Two hundred

Zahide Karakitapoğlu Aygün received her Ph.D. in social psychology from Middle East Technical University Turkey. She is currently an assistant professor at Bilkent University, Faculty of Business Administration. Her research interests concern values, commitment and justice.

Mahmut Arslan (BSc, MA, PhD) is an Associate Professor received his graduate degree from Hacettepe University Department of Public Finance. He completed a masters degree in Business Administration at Hacettepe University Department of Business Administration and his PhD in Business at University of Leeds (UK). He has worked as a financial analyst and a research assistant. Dr. Arslan has also worked for the several reorganization projects as analyst and coordinator. He became Assistant Professor in 2000 and Associate Professor in 2003 at Hacettepe University Department of Business Administration. He teaches management and business ethics, organizational behaviour. He is also the director of Hacettepe University Centre for Business and Professional Ethics.

Dr. Col. Salih Güney is an Associate Professor graduated from Hacettepe University Department of Sociology in Ankara in 1980. He received master's degree in behavioral sciences from the University of Istanbul, Faculty of Management in 1987. He finished his doctoral studies in behavioral sciences at the same university and received his PhD in 1988. He became an associated professor in 1997. He is currently the head of the behavioral sciences branch in the Turkish Military Academy. He teaches behavioral sciences, communication theory, introduction to sociology, and public relations at the Military Academy. and sixty six American and 211 Turkish university students participated in this questionnaire study. The analyses examining cross-cultural differences revealed that Turkish university students reported greater scores in the PWE and all contemporary work values as compared to their American counterparts. For the Turkish sample, there were no gender-related differences in the PWE, whereas in the U.S. sample, men reported greater PWE scores than did women. With regard to gender differences in contemporary work values, our results showed that gender groups differed in feminine and entrepreneurship values in both cultural contexts; men emphasized femininity and entrepreneurship more than women in Turkey but the reverse was true in the U.S. Correlations between contemporary work values and the PWE illustrated that the PWE is associated with entrepreneurship and masculine values in both cultural contexts and with feminine values in the Turkish context. Finally, our results regarding the role of religiosity in PWE indicated that highly religious participants reported greater PWE scores than the less religious ones regardless of culture. Findings are discussed with reference both to differences in the two socio-cultural contexts and to recent change in the social structure of Turkish society.

KEY WORDS: the Protestant work ethic, work values, masculine, feminine and entrepreneurship values, religiosity, cultural differences

\section{Introduction}

Organizational researchers refer to work values to cover a variety of notions in the work context such as business ethics and personal work preferences 
including pay, enjoyment, achievement, advancement and so on (Dose, 1997; Sagie et al., 1996). For instance, Dose (1997) defines work values as "evaluative standards relating to work or the work environment by which individuals discuss what is 'right' or assess the importance of preferences" (p. 228). She claims that work values vary across two dimensions: (1) whether the work values have a moral element, and (2) the degree of social consensus regarding the importance and desirability of particular values. Dose argues that one of the work values tapping the first dimension is the Protestant Work Ethic (PWE). Social consensus values, however, are the ones, which members of a particular culture consider as important not only for themselves, but for others as well. She lists Hofstede's (1980) cross-cultural values and altruism, individualism/independence (Super, 1973) under this second domain. Similarly, Wayne (1989) makes a distinction between historic, traditional Protestant work ethic and more modern, new, changing and contemporary values, which include less obedience and respect for authority, and less dependence on physical aspects of work. These contemporary work values are derived from the new requirements of the work in a highly technological and knowledge-based world. Therefore, combining Dose's (1997) and Wayne's (1989) formulations in the present study, we studied one moral and traditional work value, which is the PWE, and more modern and contemporary work values which can be classified as social consensus values in Dose's classification. More specifically, the first aim of this paper was to investigate how the PWE and contemporary work values were related to one another, and differed across genders and two cultural contexts, namely Turkey and the U.S. Three underlying dimensions of contemporary work values which can be classified as social consensus values in Dose's formulation were derived through factor analysis. These are feminine, masculine and entrepreneurship values.

Studying work values in the Turkish and the U.S. contexts is especially important. First of all, Turkey is underrepresented in the literature and it has unique cultural and historical characteristics. It is a democratic and secular state with a dominantly Muslim population. It is usually described as a bridge between the West and the East. It is also a candidate state to the European Union. In the early 20th century, the country transformed itself from an Islamic Empire into a modern nation-state. Although Turkey had never been colonized by Western powers, it voluntarily adopted Western values and a Western way of life starting with the early reforms in the Ottoman Empire in 1839. Turkey is also the first industrialized Muslim nation. It is believed that until 1950s, traditional Islamic values were an obstacle to modernization and industrialization of the country (Ülgener, 1981); in particular, Sufi orders were advocating a sort of other-world asceticism. Atatürk, the founder of the Republic, had outlawed all of the Sufi orders in the 1930s, but some had persisted under different names. After the 1950s, the Sufi orders started to advocate industrialization; it was a shift from other-world asceticism to this-world asceticism. Hard work and business activities were interpreted as a kind of worship, a way of glorifying God. Such a belief was very similar to the Calvinistic approach to work in Europe (Arslan, 1999). In this way, changing Turkish work attitudes may be similar to the historical PWE characteristics that Weber (1985) described in his famous work, "The Protestant Ethic and Spirit of Capitalism". A comparison of Turkey with other countries may be expected to reveal the direction of this social change in Turkey regarding work values. A few studies has compared Turkey with Britain and Ireland in terms of the PWE (Arslan, 2000, 2001), but there is no research comparing Turkey and the U.S. despite the fact that the U.S. is the most powerful capitalist country in the world and also represents the homeland of the PWE. The present study aims to fill this gap in the related literature.

Another aim of the present study was to investigate the role of religiosity in the PWE across the above-mentioned cultural groups. Weber initially explained the role of Calvinism in the development of capitalism through 'the spirit of capitalism'. He claimed that the new morality and its religious framework encouraged hard work and productivity. Weber's thesis stimulated considerable research on the relationship between religiosity and work attitudes. However, few studies included both Muslim and Christian groups. The World Values Survey (http://www.worldvaluessurvey.org, 2004) showed that Turkey and the U.S. are among the five most religious nations of the 43 studied. Therefore, we chose Turkey and the U.S. and compared the PWE 
preferences of university students from these two cultures. In addition, we examined the role of the individual's level of religiosity (participants' descriptions of themselves as religious in their personal lives) in the PWE endorsement; this sheds further light on the link between religiosity and work attitudes.

\section{The Protestant work ethic}

Some types of work values such as hard work, industriousness, or attitudes towards money and time saving which are usually known as dimensions of the PWE, are simply a business ethics issue. All business actions can be affected by individual work values. Business ethics is the study of business action individual or corporate - with special attention to its moral adequacy. Therefore, individual level ethical beliefs towards work such as virtue ethic, leisure ethic and Protestant work ethic are part of business ethics. In short, the PWE can be considered under the micro level business ethics as a group or individual behavior at the work place.

The PWE typically refers to hard work, industriousness, a negative attitude to leisure activities, and internal locus of control (Furnham, 1989, 1990). In other words, it has been defined as a general orientation to hard work, a need for achievement and a strong sense of duty (Banks, 1998; Jones, 1997). Although it has been defined in different terms, many studies that measure the PWE seem to be referring to one major dimension, which is hard work. Furnham's (1990) factor analysis of seven surveys revealed five factors. However, the first factor was the strongest (accounting for $17.3 \%$ of the variance) referring to respect for, admiration of and willingness to hard work. Other factors such as attitudes toward leisure, asceticism etc., were not as strong as the hard work domain. Since attitudes and behaviors oriented to hard work are the core elements of the PWE, mostly hard work items were used in the present study while measuring the PWE.

Weber was the first to put forward the idea that a commitment to the PWE in a culture is related to economic development. Later on, McClelland (1961) claimed that some cultures lag behind in economic development since those cultures do not possess a strong need for achievement. In the 18th century, the PWE flourished in the U.S. with the help of Non-conformist immigrants from Europe such as Quakers, Methodists, and Baptists. Weber (1985) argued that non-conformist Protestant movements represent "the spirit of capitalism". Currently the U.S. is the largest capitalist economy in the world and the heart of PWE after its birth in England. One may, therefore, expect the U.S. students in our study to report greater PWE scores than the Turkish respondents (Feather, 1998; Triandis, 1995; Spence, 1985). However, recent studies challenge this assumption. Studies conducted in Asian and other developing cultures generally indicate that the PWE is no longer found only in cultures where a Protestant value system is dominant (Furnham, 1991; Furnham et al., 1993; Furnham and Muhiudeen, 1984; Niles, 1994; 1999). For example, Tang and Tzeng (1992) suggested that “ the PWE today cannot be defined as it was in early America, because Americans, ... now live in a society where only the experience of the moment is important and pleasure is the overriding goal" ( $p$. 164). Moreover, Furnham et al. (1993) measured the PWE values in 13 cultures and showed that participants from richer, First World countries tended to have lower scores than those from Third World countries. In other words, they found that Third Word countries that score high on power distance (have large inequalities between rich and poor) and collectivism seem to emphasize the PWE most. As a matter of fact, in the above-mentioned study comparing 13 nations (Furnham et al., 1993), the U.S. ranked in the middle in terms of the PWE, coming after other underdeveloped, high power distance countries such as India, South Africa and Zimbabwe.

In sum, recent cross-cultural studies on the PWE usually suggest that conservative, collectivistic, underdeveloped countries which score high on power distance tend to report greater PWE than relatively liberal, individualistic, developed countries which are low in power distance. They also suggested that it is inappropriate to refer to work ethic as the Protestant work ethic since most religions and cultures appear to have a "common concept of work ethic when it is defined as a commitment to hard work and to excellence" (Niles, 1999; p. 865). Therefore, it would be useful to examine this construct in nonProtestant countries as we did in the present study. While studying the PWE in Turkey, a Muslim 
country and comparing it with a predominantly Protestant culture, we construed work ethic as an issue, which changes according to the "socioeconomic needs of the system" (Niles, 1999). Such a socio-cultural perspective suggest that we should consider contextual information to fully understand the PWE such as culture, gender or combination of both, which was one of the aims of the present study.

As in the above-mentioned cultures, the traditional Turkish context is supportive of the PWE. In a well-known study, in which achievement orientation is regarded as a strong aspect of the PWE, McClleland (1961) found that the Turkish youngsters reported having very high scores in need for achievement compared to youth from other countries. This was the first cross-cultural finding pointing to higher endorsement of the PWE among Turkish people in the late 1950s. Arslan's (2000; 2001) findings in the late 1990s were consistent with McClelland's results. In his cross-cultural studies comparing Muslim, Catholic and Protestant managers, Arslan found that Muslim Turkish managers had a higher work ethic than Catholic Irish and Protestant British managers. He explained the higher PWE endorsement of Turkish respondents by their belief system, and by the political and economical situation in which they work. The negative impacts of Ottoman despotism were minimised through democratic reforms in recent years and traditional Sufism was transformed into a kind of entrepreneurial ideology (Roos and Roos, 1971). Thus, in line with the above-noted cross-cultural findings we predicted that;

H1: Turkish students will have higher PWE scores than their American counterparts

In line with our socio-cultural understanding of the PWE, another aim of the present study was to elucidate gender-related differences in the endorsement of PWE. Related studies overall yielded inconsistent results. For example, Furnham and Muhiuedeen (1984) found that women were more likely than men to report greater PWE scores. On the other hand, the results of Mirels and Garret (1971), Tang (1989), Tang and Tzeng (1992), and
Ma (1986) suggested that gender is not related to the PWE. Since past research revealed inconsistent findings, no specific hypotheses were derived for gender differences in the PWE in our cultural groups; rather, the aim was exploratory.

\section{Contemporary work values}

As mentioned before, in her theoretical formulation of work values, Dose (1997) defined more contemporary cross-cultural values, altruism, individualism/independence (Hofstede, 1980; Super, 1973) as social consensus values. In his seminal work, Hofstede (1980) found significant differences in the work values of 160,000 employees and managers from 40 different countries. He identified four dimensions of culture: individualism-collectivism, power distance, uncertainty avoidance and masculinity-femininity. Of particular importance, work values of masculinity and femininity were investigated in the present study. Hofstede (1980) defined masculinity as the extent to which the dominant values in a culture emphasize assertiveness and the acquisition of money and materialism. He defined femininity as the extent to which the dominant values in a culture emphasize relationships among people, concern for others and overall quality of life. In addition to masculine and feminine values, entrepreneurial values were also examined in the present study. Entrepreneurship orientation has been characterized by achievement orientation and moderate risk-taking in the literature. It implies a high tolerance of uncertainty, creativity, high energy level and a willingness to take personal responsibility for success and failure (Thomas and Mueller, 1998). As explained below, these values were chosen since they are expected to reveal more informative data by comparing one economically stable, personal achievement-oriented culture (i.e., the U.S.) with a more transitionary culture which has been fundamentally characterized by close social bonds, but now experiencing a rapid social change from traditionalism to modernism (i.e., Turkey).

The U.S. and Turkey appears to be opposite in terms of contemporary work values. The traditional Turkish culture has been defined as collectivistic, hierarchical and feminine (Hofstede, 1980). The U.S., in contrast, has been defined as one of the most 
individualistic and masculine cultures where independence, individual initiative, success and achievement are emphasized (Hyman et al., 1958). For example, Feather (1998) found that achievement values received greater importance in the U.S. as compared to two other individualistic cultures, Australia and Canada. In such a culture, "success is communicated, shared and displayed because it is natural to show off' (De Mooij, 1998, p. 195). Thus, the U.S. culture is likely to encourage masculine characteristics emphasizing money, assertiveness, competition, and financial success over 'soft,' 'feminine' values such as quality of life, warm personal relationships, and service (Hofstede, 1980).

Supporting Hofstede's findings, related studies in Turkey generally showed that internal cognitive values such as honesty, using one's time efficiently and being successful were given the greatest importance (Örücü et al., 2003; T1naz, 1996). Sargut (2001) found that feminine values such as thoughtfulness, empathy, being loving toward children were attributed greater importance than masculine values by Turkish university students. Aldemir et al. (2003) argued that Turkish work values are not based on rationality, but on social solidarity and are emotional in nature. Despite its traditionally feminine character, Turkey is in a time of transition in which masculine and feminine characteristics coexist. Since the radical economic transformations of the 1980s, hard work, being successful, gaining power and social status in the social system have become more dominant (Karakitapoğlu Aygün and Imamoğlu, 2002). For example, Ergüder et al. (1991) pointed out that educated modern Turkish people endorse the values of achievement motivation, risk-taking, entrepreneurship, working extensively and planning one's time, and trying to get a higher income. This change toward individualism, achievement and increased competition tend to be more salient among urban Turkish youth. Traditional values such as "humility, sharing and equality, respect to authority and family are replaced by competition, achievement and promotion of self-interest" among modern Turkish youth (Aycan and Fikret-Paşa, 2003, p. 132). They emphasize 'high salary' and 'sense of achievement' as well as 'good interpersonal relationships' and 'peaceful work environment' (Aycan and Fikret-Paşa, 2003). Supporting this co-existence of masculine and feminine attributes, Demirutku (2000) found that need for achievement was rated highest by Turkish people, followed by need for affiliation. Pointing to the preferences for both achievement and social relationships simultaneously, he found the correlation between the need for achievement and affiliation very high $(r=0.43)$. Thus, in line with both McClelland's (1961) finding and the above-mentioned studies, both masculine and feminine values may be expected to be important for our Turkish people. They may even be expected to value money, accumulation of wealth, status, etc. more than their American counterparts since they have experienced a sharp transition from traditionalism to competition, success and individualism. Hence, we proposed the following hypothesis regarding masculine and feminine values:

H2a: Turkish respondents are expected to hold and combine both masculine and feminine characteristics in their value preferences, and rate them significantly higher than their American counterparts.

Regarding entrepreneurship values, Lodge (1975) argued that individualistic cultures (such as the U.S.) tend to score high in entrepreneurship orientation since individuals in these cultures are more interested in exploring new ways of doing things and are more willing to take risks. In a similar vein, McGrath et al. (1992) claim that the tendencies toward independent action, taking chances, and self-reliance in the U.S. promote an entrepreneurship orientation. As indicated by Hull et al. (1985), “... the American public has long regarded entrepreneurship as a time-tested way to realize the American dream". In such an individualistic context, having autonomy, making individual decisions and showing initiative are very important and socially encouraged. However, in collectivistic and economically unstable environments such as Turkey, having security and making group decisions are important, and individual initiative tends to be discouraged. An entrepreneurial orientation requires individualistic and risk-taking attitudes (Wickham, 2003) that are not encouraged much in the traditional Turkish culture. Therefore, 
we proposed the following hypothesis regarding entrepreneurship:

H2b: American students will have higher scores in entrepreneurship values than their Turkish counterparts.

Some research has also considered gender as a possible correlate of work values. In an early work, Hoffman (1972) found that women are motivated by desire for love, approval and social approbation, whereas men are motivated by mastery striving and a desire for excellence. A consistent finding is that men are more likely to be concerned with money, rewards, competitiveness, dominance and long-term career goals (Elizur, 1994, Lynn, 1993; Sagie et al., 1996). However, women tend to be concerned with social approval, short-term career goals and they tend to be people oriented. In line with their traditional gender role socialization, men seem to attribute more importance to instrumental values (e.g., pay) and cognitive values (e.g., influence, independence and responsibility); women, however, emphasize affective values (e.g., esteem, coworkers, opportunity for interaction with people, fair and considerate supervisor) (Elizur, 1994, Lynn, 1993; Sagie et al., 1996). Similar results were obtained by studies conducted in Turkey. In one study (Örücü et al., 2003), Turkish men were found to attribute more importance to having responsibility, being disciplined and being knowledgeable than women. This can be explained by the traditional gender roles in Turkey; in almost all areas of life men are the responsible authority figures. Thus, the third hypothesis of the paper is:

H3: Compared to women, men are expected to have higher scores in masculine and entrepreneurship values and lower scores in feminine values in each cultural context.

\section{The PWE and other constructs}

Research on the PWE usually looked at the demographic correlates of the PWE, but ignored its relationship to other constructs such as more modern work values and religiosity. To our knowledge, only one study (Wayne, 1989) investigated the PWE and contemporary work values simultaneously. In a similar vein, there is no research studying the linkages between the PWE and individual perceptions of religiosity. Exploring these relationships in different cultural contexts will contribute to our socio-cultural understanding of historical PWE characteristics. The related literature will be reviewed below.

\section{The PWE and contemporary work values}

As mentioned before, the PWE includes the traits of industriousness, individualism and overall valuing of work as the most worthwhile way to spend one's time. It emphasizes achievement orientation and instrumental components such as seeking monetary gain, prestige etc (Sagie et al., 1996). Believers in the PWE then, are independent, hard-working and competitive individuals who tend to show perseverance to achieve desirable ends. Thus, the PWE seems to be correlated with hard work, instrumentalism and individualism. Since the PWE beliefs have been shown to have both motivational and performance correlates, it is reasonable to expect the PWE to significantly correlate with both masculine and entrepreneurship values in both cultural contexts in the present study.

Moreover, studies from Turkey refer to the coexistence of achievement and relationship concerns in recent years (Demirutku, 2000; Karakitapoğlu Aygün and Imamoğlu, 2002; Phalet and Claeys, 1993). In one of the studies mentioned above (Demirutku, 2000), the correlation between achievement and affiliation needs was found to be very high, paralleling our variables of the PWE and feminine values. As Phalet and Claeys (1993) conclude, in Turkey

achievement motive appears to be tied up with filial loyalty and with the prospect to gratify one's family for their sacrifices and to live up to their pride by being successful and responsible. This is in accordance with other cross-cultural findings on non-Western achievement motive, revealing a group oriented work ethic with loyalty instead of Western individualistic achievement with autonomy (p. 339). 
Therefore, feminine values may also be expected to correlate with the PWE in the Turkish context. Accordingly, the fourth hypothesis of the study is:

H4: The PWE will be positively correlated with masculine and entrepreneurship values in both cultural contexts and with feminine values in the Turkish context.

\section{The PWE and religiosity}

Religiosity has been defined as an important determinant of economic behavior. The relationship between religion/religiosity and business ethics is a very well known issue in the business ethics literature. Ethical principles about business activities are involved in the main religious belief systems of the world such as Christianity, Islam, Buddhism and Judaism. For example Islam forbids the use of usury, (i.e., income through rate of interest) and trade of pork and alcoholic drinks for its believers. Similarly, work and profession is seen as a calling of God in the Protestant branches of Christianity. Some belief systems, for instance Calvinism, strongly promote other-world activities and work oriented attitudes. Therefore, religion can affect business activities and decisions through religious attitudes towards work and business.

Weber, in the early 20th century, argued that Protestantism encourages entrepreneurial activity, which is essential for economic development. Since then the number of studies investigating the role of religiosity in PWE is scant and the results are equivocal. Some found no significant relationship between the PWE endorsement and specific religious affiliation (Beit Hallahmi, 1979; Chushmir and Koberg, 1988; Kim, 1977; Ma, 1986; Ray, 1982), whereas some others found weak relationship between Protestant affiliation and the PWE (Cohen, 1985, Mayer and Sharp, 1962). These studies usually looked at the relationship between religious affiliation and the PWE, ignoring the individual perceptions of religiosity. With these in mind, the present study aimed to elucidate the role of an individual's perceptions of religiosity in the PWE endorsement. In other words, the study tried to answer the ques- tion "Are there differences in the PWE between individuals who describe themselves as more religious and those who consider themselves less religious in their personal lives?". To our knowledge, there is no research tackling this question. Related research has concluded that people who believe in the PWE tend to be more rigid and have more conservative attitudes and beliefs (Atih et al., 1987; Feather, 1984; Furnham and Bland, 1983; Tang and Tzeng, 1992). In line with these findings, regardless of culture, highly religious individuals may be expected to endorse more PWE as compared to those who are less religious. Thus, our hypothesis is:

H5: Religiosity is expected to have a significant effect on PWE regardless of culture, with highly religious individuals reporting more PWE than less religious individuals.

In summary, the current study, investigates the traditional and more modern work values among two cultural (namely Turkey and the U.S.) and gender groups as well as the role of religiosity on the traditional PWE attitudes. It uses a student sample. Although not yet in the work life, our student sample can be said to represent the future generation of managers. ${ }^{1}$ They are individuals searching for entry-level positions in the work force in business life. Actually, we asked perceptions of students about their future work life. One's "perceptions" rather than the actual experiences may have stronger potential impact on principles and practices in work life. One can also argue that even students, as potential employees and managers, still hold to their work values. Supporting this argument, for example, Wenthworth and Chell (1997) illustrated that it was the younger and undergraduate students who expressed greater belief in the PWE. They conclude that "PWE is still being exhorted as the path to follow and the ethic is instilled in many college students at a young age" (p. 293). Finally, many studies in the literature have investigated work values among managers and working groups. Our aim is to complete the picture and provide a better understanding of work values by studying nonworking groups. 


\section{Method}

Participants

The sample consisted of 477 Turkish and American university students.

American the U.S. sample

A sample of 266 undergraduate students (121 male, and 145 female; mean age 18.95, $S D=0.94)$ from the University of Michigan participated in the study. Students were recruited from the Psychology Department Subject Pool. The sample was predominantly Euro-American, with $75.6 \%$ identifying as Euro-American, $7.5 \%$ as Asian-American, $7.9 \%$ as African-American, $4.1 \%$ as Latin-American and $4.9 \%$ other. All of them were born in the U.S.

\section{Turkish sample}

The Turkish university sample consisted of 211 undergraduate students (125 male, and 84 female, 2 not indicated; mean age 20.46, $S D=1.77$ ) from different departments of Bilkent University and Hacettepe University in Ankara. In terms of parental education, most of the respondents were from middle and upper middle socio-economic status families.

The universities that we chose in the U.S. and Turkey were comparable in the sense that they are among the most prestigious and well-established universities in each culture. However, the samples were not comparable in terms of age and parental education. The education level of the American parents was higher than that of the Turkish sample. Majority (80\%) of American parents were college graduates or post-graduates, while only $47 \%$ of Turkish parents were so. Therefore, as noted later, age and parental education was considered as covariates while investigating cross-cultural differences.

\section{Instruments}

Protestant work ethic

A short form of Mirels and Garret's (1971) PWE scale was used in the present study to measure the protestant work ethic. We originally used 11 items.
After some preliminary analyses, we deleted two of the items that were problematic. ${ }^{2}$ The final scale, which included 9 items, mostly consisted of hard work attitudes. Items were measured using a 7-point response scale ranging from 1 (strongly disagree) to 7 (strongly agree). The reliability coefficients were 0.74 for the Turkish sample and 0.69 for the American sample.

\section{Contemporary work values}

Those values were measured with Pratto, Stallworth, Sidanius and Sier's (1997) scale. Participants rated the importance of each value on a 7 -point scale ranging from 1 (not at all important) to 7 (very important). In order to check for the common factorial structure of work values, separate factor analyses (with varimax rotation) were conducted for each culture. Some of the items which have loadings under 0.40, low communality and reduce internal consistency were deleted resulting in a total of 21 items (out of 24). ${ }^{3}$ As shown in Table I, the same factorial pattern was found in each culture (explaining about 49\% of the total variance) and reliabilities were satisfactory for both groups. The first factor was labeled masculine values since it included items related to gaining personal power, prestige, and having high income and status. The second factor was named feminine values, as it was related to having humanitarian and egalitarian concerns (e.g., helping others, serving the community, being part of a team etc.). Finally, the third factor was labeled entrepreneurship values, since it involved items about opportunities for advancement, helping one's organization get ahead and making decisions independently. However, there were some cross-loadings for some of the items. First, "working with smart people" also loaded under entrepreneurship domain. Moreover, "helping your organization get ahead" loaded under feminine values for the Turkish sample and under masculine values for the American sample. Finally, "opportunities for advancement" loaded under masculine values in the American sample. Those items were computed under the factor which has the greatest loading.

\section{Religiosity}

It was measured with a single item "how religious do you consider yourself to be?" Respondents rated the item on a 7-point scale ranging from 1 (not at all religious) to 7 (very religious). 
TABLE I

The results of factor analysis on work values

\begin{tabular}{ccc}
\hline Items & Factor & Factor \\
loadings & loadings for \\
for Turks & Americans
\end{tabular}

Masculine values

\begin{tabular}{|c|c|c|}
\hline Gaining personal prestige & 0.79 & 0.81 \\
\hline Having a high income & 0.78 & 0.81 \\
\hline Having high social status & 0.78 & 0.82 \\
\hline Gaining personal power & 0.71 & 0.79 \\
\hline $\begin{array}{l}\text { Gaining the approval } \\
\text { of your employer }\end{array}$ & 0.62 & 0.45 \\
\hline Being famous & 0.60 & 0.64 \\
\hline Working with the elite & 0.59 & 0.73 \\
\hline Working with smart people & 0.41 & 0.47 \\
\hline Explained Variance & 24.71 & 25.07 \\
\hline Eigenvalue & 5.19 & 5.27 \\
\hline Alpha value & 0.81 & 0.87 \\
\hline \multicolumn{3}{|l|}{ Feminine values } \\
\hline Working with people & 0.76 & 0.67 \\
\hline Serving the community & 0.68 & 0.77 \\
\hline Helping others & 0.66 & 0.71 \\
\hline Being part of a team & 0.62 & 0.69 \\
\hline Aiding subordinate coworkers & 0.59 & 0.40 \\
\hline Working with the disadvantaged & 0.58 & 0.74 \\
\hline Aiding senior coworkers & 0.58 & 0.42 \\
\hline Explained Variance & 15.89 & 17.01 \\
\hline Eigenvalue & 3.34 & 3.57 \\
\hline Alpha value & 0.77 & 0.78 \\
\hline \multicolumn{3}{|l|}{ Entrepreneurship values } \\
\hline Opportunities for advancement & 0.72 & 0.49 \\
\hline Making decisions independently & 0.72 & 0.64 \\
\hline Gaining respect for your work & 0.71 & 0.52 \\
\hline Working with honest people & 0.64 & 0.67 \\
\hline Being creative & 0.61 & 0.54 \\
\hline $\begin{array}{l}\text { Helping your organization } \\
\text { get ahead }\end{array}$ & 0.49 & 0.46 \\
\hline Explained variance & 8.84 & 7.05 \\
\hline Eigenvalue & 1.86 & 1.48 \\
\hline Alpha value & 0.79 & 0.68 \\
\hline
\end{tabular}

Procedure

The Turkish versions of the scales were checked through back translations. Then, 6 Turkish graduate students checked for the wording, accuracy and clarity of items in Turkish. Questionnaires were group-administered to students in class. A one-point bonus was given to the students for their participation, which was on a voluntary basis. All the respondents were assured that their responses would be anonymous and confidential.

\section{Results}

Since the Turkish and U.S. samples were not comparable in terms of age and parental education, these variables were statistically controlled. First, in order to explore cross-cultural and gender differences in work values and the role of religiosity in the PWE, separate ANCOVAs and MANCOVAs (parental education and age as covariates) were conducted, as explained below. Then, the correlations between the PWE and other work values were considered for the two cultural groups. Unadjusted means, standard deviations and zero-order correlations (not controlling for the age and parental education) of major and demographics variables for each cultural context are provided in Table II. ${ }^{4}$

\section{Cross-cultural and gender differences in the PWE}

In order to explore cross-cultural and gender differences in the PWE, 2 (culture: Turkey, U.S.A.) $\times 2$ (gender: men, women) ANCOVA (parental education and age as covariates) was conducted. The rationale for such a design is that it is possible to consider the interplay of culture and gender in work values. As a matter of fact, gender roles are embedded in socio-cultural characteristics. Therefore, it is possible to see the interactions between culture and gender in work values by using such a design. However, we did not derive hypotheses regarding those interactions to keep the paper simple.

Culture main effect was found to be significant, $(F(1,461)=17.45, p<0.001)$. As shown in Table III, Turkish respondents reported higher PWE scores than their American counterparts. However, this main effect was qualified by a significant culture $\times$ gender interaction, $(F \quad(1$, 


\section{TABLE II}

Unadjusted means, standard deviations and correlations of major variables (not controlling for age and parental education)

\begin{tabular}{|c|c|c|c|c|c|c|c|c|c|}
\hline U.S.A. $(N=261-266)$ & $M$ & $S D$ & 2 & 3 & 4 & 5 & 6 & 7 & 8 \\
\hline 1. Age & 18.95 & 0.94 & $-0.16^{\star \star}$ & -0.08 & -0.04 & -0.10 & 0.06 & -0.01 & -0.07 \\
\hline 2. Sex & 1.55 & 0.50 & - & -0.01 & $-0.24 \star \star \star$ & -0.10 & $0.23 \star \star \star \star$ & $0.15^{\star}$ & 0.10 \\
\hline 3. Parental education ${ }^{a}$ & 5.27 & 0.59 & & - & $-0.15^{\star}$ & 0.05 & -0.01 & 0.04 & 0.09 \\
\hline 4. PWE & 4.34 & 0.74 & & & - & $0.21 \star \star$ & 0.03 & $0.16^{\star}$ & 0.07 \\
\hline 5. Masculine values & 4.96 & 1.11 & & & & - & 0.03 & $0.43^{\star \star \star}$ & -0.05 \\
\hline 6. Feminine values & 5.07 & 0.92 & & & & & - & $0.38 \star \star \star$ & 0.09 \\
\hline 7. Entrepreneurship values & 5.96 & 0.67 & & & & & & - & 0.09 \\
\hline 8. Religiosity & 3.52 & 1.76 & & & & & & & - \\
\hline \multicolumn{10}{|l|}{ Turkey $(N=207-210)$} \\
\hline 1. Age & 20.46 & 1.77 & $0.37 \star \star \star \star$ & 0.10 & -0.09 & 0.04 & -0.03 & 0.02 & 0.07 \\
\hline 2. Sex & 1.40 & 0.49 & - & -0.03 & 0.10 & -0.08 & $-0.19 \star$ & $-0.30 \star \star \star$ & 0.03 \\
\hline 3. Parental education & 4.45 & 0.97 & & - & $-0.15^{\star}$ & 0.04 & $-0.18^{\star \star}$ & .00 & $0.33 \star \star \star \star$ \\
\hline 4. PWE & 4.77 & 0.86 & & & - & $0.26 \star \star \star \star$ & $0.20 \star \star$ & $0.21 \star \star$ & $0.24 \star \star \star \star$ \\
\hline 5. Masculine values & 5.63 & 0.88 & & & & - & $0.19 \star \star$ & 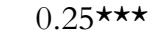 & $0.17^{\star}$ \\
\hline 6. Feminine values & 5.59 & 0.80 & & & & & - & $0.47 \star \star \star \star$ & $0.26^{\star \star \star}$ \\
\hline 7. Entrepreneurship values & 6.58 & 0.50 & & & & & & - & 0.12 \\
\hline 8. Religiosity & 3.88 & 1.72 & & & & & & & - \\
\hline
\end{tabular}

${ }^{a}$ Parental education was measured on a 6 -point scale: $1=$ illiterate, $2=$ primary school, $3=$ junior high school, $4=$ high school, $5=$ college, $6=$ post-graduate

$\star_{p}<0.05,{ }^{\star} p<0.01,{ }^{\star \star \star} p<0.001$

TABLE III

Adjusted means, standard deviations, and univariate F values of the variables for the turkish and the U.S. samples (after controlling for parental education and age)

\begin{tabular}{lllllll}
\hline & \multicolumn{2}{c}{ Turkey } & & \multicolumn{2}{c}{ U.S.A. } & \multirow{2}{*}{$F$} \\
\cline { 2 - 3 } \cline { 5 - 6 } & $M$ & $S D$ & & $M$ & $S D$ & \\
\hline PWE & 4.78 & 0.84 & 4.38 & 0.75 & $14.06^{\star \star \star}$ \\
Masculine values & 5.67 & 0.88 & & 4.93 & 1.11 & $34.55^{\star \star \star}$ \\
Feminine values & 5.48 & 0.81 & & 5.11 & 0.92 & $12.51^{\star \star \star}$ \\
Entrepreneurship values & 6.54 & 0.50 & & 5.96 & 0.67 & $61.06^{\star \star \star}$ \\
\hline
\end{tabular}

$\star \star \star p<0.001$, Degree of freedom $=1$ and 461-464.

$461)=16.19, p<0.001)$. As shown in Table IV, there were no differences between Turkish men and women. However, in the U. S. sample, men had higher PWE scores than women. Moreover, within-gender comparisons showed that both Turkish men $(p<0.01)$ and women $(p<0.001)$ had higher PWE scores than their American counterparts. 
TABLE IV

Gender $\times$ culture interaction for PWE and $\mathrm{WV}^{\mathrm{a}}$

\begin{tabular}{|c|c|c|c|c|c|c|c|c|c|c|}
\hline & \multicolumn{4}{|c|}{ Turkey } & \multirow[t]{3}{*}{$F^{\mathrm{b}}$} & \multicolumn{4}{|c|}{ U.S.A. } & \multirow[t]{3}{*}{$F^{c}$} \\
\hline & \multicolumn{2}{|c|}{ Men } & \multicolumn{2}{|c|}{ Women } & & \multicolumn{2}{|c|}{ Men } & \multicolumn{2}{|c|}{ Women } & \\
\hline & $M$ & $S D$ & $M$ & $S D$ & & $M$ & $S D$ & $M$ & $S D$ & \\
\hline PWE & 4.66 & 0.79 & 4.89 & 0.89 & 3.49 & 4.57 & 0.65 & 4.19 & 0.79 & $18.31 \star \star \star$ \\
\hline Masculine values & 5.71 & 0.89 & 5.54 & 0.82 & 1.69 & 5.11 & 1.11 & 4.84 & 1.12 & 3.56 \\
\hline Feminine values & 5.74 & 0.73 & 5.39 & 0.88 & $8.13 \star \star$ & 4.81 & 1.04 & 5.29 & 0.78 & $17.78 \star \star \star$ \\
\hline Entrepreneurship values & 6.73 & 0.37 & 6.37 & 0.61 & $24.01 \star \star \star$ & 5.85 & .66 & 6.05 & 0.66 & $5.95^{\star}$ \\
\hline
\end{tabular}

${ }^{a}$ Means are adjusted for age and parental education

${ }^{\mathrm{b}}$ Degrees of freedom $=1$ and $201-203$

${ }^{\mathrm{c}}$ Degrees of freedom $=1$ and $255-256$

$\star_{p}<0.05,{ }^{\star} \star_{p}<0.01,{ }^{\star} \star^{\star} \star_{p}<0.001$

Cross-cultural and gender differences in contemporary work values

In order to explore cross-cultural and gender differences in those work values, $2 \times 2$ MANCOVA using three-work values as dependent variables was conducted. Culture main effect was again found to be significant, $(F(1,457)=23.66, p<0.001)$. As shown in Table III, all univariate effects were significant. Turkish students reported higher scores on all value items as compared to their American counterparts. However, this main effect was qualified by a significant culture $\times$ gender interaction, $(F(1$, $457)=13.21, p<0.001)$. This interaction was significant for feminine and entrepreneurial values, $F(1$, $459)=24.05, p<0.001$ and $F(1,459)=21.75$, $p<0.001$, respectively. As shown in Table IV, American women had higher scores on feminine and entrepreneurial values than American men. Turkish men, on the other hand, had higher scores in feminine and entrepreneurial values than Turkish women. Moreover, within-gender comparisons revealed that Turkish men reported higher scores in feminine and entrepreneurial values than American men, whereas Turkish and American women did not differ in any of their value preferences.

\section{The role of religiosity in the PWE}

In order to explore the role of religiosity in the PWE, a 2 (culture: Turkey, U.S.A.) $\times 2$ (religiosity: high, low) ANCOVA was conducted. ${ }^{5}$ Participants who scored below the median were put in the low religiosity group; the others were in the high religiosity group. Religiosity main effect was found to be significant, $(F(1,460)=4.76, p<0.05)$. As expected, highly religious participants reported greater PWE scores $(M=4.62)$ than the less religious ones $(M=4.45)$. Religiosity $\times$ culture interaction was not significant.

Correlations between the PWE and contemporary work values

First, regarding the inter correlations among work values, we found that all dimensions of work values were correlated with each other for the Turkish sample (Table V). In the American sample, however, masculine and feminine values were found to be related to entrepreneurship values, but not correlated with each other. Secondly, the PWE was positively correlated with all dimensions of contemporary work values in Turkey. In the U.S., on the other hand, the PWE was positively associated with masculine and entrepreneurship values, but not with feminine values.

The significances of the differences in correlations across contexts were tested using Fisher Z-transformation. Most of the comparisons indicated differences in correlations across contexts to be nonsignificant. However, correlations between masculine and entrepreneurship values were found to be different 
TABLE V

Correlations between PWE and WV (after controlling for parental education and age)

\begin{tabular}{lllll}
\hline & \multicolumn{1}{c}{1} & \multicolumn{1}{c}{2} & \multicolumn{1}{c}{3} & \multicolumn{1}{c}{4} \\
\hline 1. PWE & - & $0.24 \star \star \star$ & $0.19 \star \star$ & $0.23^{\star \star \star}$ \\
2. Masculine values & $0.25 \star \star \star$ & - & $0.20^{\star \star}$ & $0.25^{\star \star \star}$ \\
3. Feminine values & 0.03 & 0.03 & - & $0.48^{\star \star \star}$ \\
4. Entrepreneurship values & $0.20 \star \star \star$ & $0.43 \star \star \star$ & $0.38 \star \star \star$ & \\
\hline
\end{tabular}

Note. The lower part of the table refers to American sample $(N=255-266)$ and the upper part to the Turkish sample $(N=200-209)$

$\star_{p}<0.05, \star \star p<0.01, \star \star \star p<0.001$

across our cultural contexts $(p<0.05)$. Moreover, differences involving the correlations between the PWE and feminine values, as well as correlations between feminine and masculine values approached significance, although they were not statistically significant.

\section{Discussion}

The present findings suggest several implications for our understanding of the traditional PWE and contemporary work values; the implications will be discussed under different headings. First, cross-cultural and gender differences in work values will be considered. Second, the relationship between the PWE and contemporary work values, and the role of religiosity in the PWE will be considered. Finally, some limitations, strengths and implications of the present research will be noted.

\section{Cross-cultural and gender differences in the PWE}

Supporting our hypothesis, Turkish university students reported greater PWE scores than their American counterparts. This finding can be explained by some factors peculiar to Turkish society such as high achievement orientation (McClelland, 1961), the transformed Islamic work ethic, the secular education system resulting from Ataturk's reforms promoting hard-work and dynamism of an emerging economy. In line with Arslan's (1999, $2000,2001)$ arguments, the results imply that traditional 'other-world Turkish Sufism' is moving into a 'this-worldly asceticism'. It seems that both religious and secular movements in Turkey encourage a work ethic. Our results are also consistent with previous research, which found Muslim Turkish managers to have higher PWE scores than Protestant British and Catholic Irish managers (Arslan, 1999, 2000, 2001). From those studies, Arslan concluded that the PWE is becoming more prevalent in Turkey in recent years. Thus, when the PWE is defined as a respect for and willingness to take part in hard work, our Turkish university students seem to report higher scores than their American counterparts. Therefore, although it used a student sample, our study contributes to cross-cultural research by comparing a Muslim country with a predominantly Protestant culture and by suggesting that the PWE should be considered within a socio-cultural and religious history.

As mentioned in the introduction, many crosscultural studies investigating the PWE suggest that an ethic of hard work is no longer found only in cultures characterized by dominant Protestant value system. As indicated by Niles (1994), "much of the evidence seems to suggest that the work ethic is stronger in some developing countries than in the developed world". Present findings are supportive of such recent cross-cultural data, which imply that developing countries scoring high in collectivism, conservatism and power distance emphasize the PWE most (Furnham et al., 1993; Furnham and Muhiudeen, 1984). Hence, the hierarchical, conservative and collectivistic nature of Turkish society can also explain the above-mentioned differences between our Turkish and American respondents in the PWE endorsement. 
This particular study yielded no gender-related differences in the PWE in Turkey, but did so in the U.S. Greater endorsement of the PWE by American men than women is not surprising given the traditional gender roles which emphasize independence, achievement and success on the part of men (Elizur, 1994). However, the similarity in the PWE preferences of Turkish men and women is interesting. It can be explained by the impact of socio-cultural change in Turkey on women's roles (Kağıtçıbaş1, 1986); with increasing education and socio-economic development, women are more likely to express a concern with individualism and achievement. Kağıtç̧ıbaşı (1977) suggests that in urban metropolitan areas, women possessing "modern" characteristics are exposed to conflicting pressures: the traditional role expectations, on the one hand, and their own expectations and ideals determined by their education, on the other hand. Therefore, in line with recent trends toward independence and liberalism, even women can show a great deal of concern with achievement and hard work. It should also be noted that the Turkish sample was composed of university students living in an urban metropolitan area of Turkey. For women, pursuing a university degree may require emphasizing hard work in order to be able to achieve and survive in an individualistic competitive environment.

Cross-cultural and gender differences in contemporary work values

Our hypothesis that Turkish respondents would hold and combine both feminine and masculine values and report higher scores in those values in contrast to their American counterparts was supported. Turkish respondents' higher ratings on both femininity and masculinity are in line with Hofstede's (1980) findings and the results of other Turkish studies (Aldemir et al., 2003; Aycan and Fikret-Paşa, 2003; Demirutku, 2000; Örücü et al., 2003; Sargut, 2001). Again, the unstable economic system and unique socio-cultural context of Turkish society mentioned above may be responsible for the coexistence of feminine values emphasizing a harmonious work environment with increased concern with money, power, status, wealth and advancement. In view of the recent transition in values, it is understandable that our Turkish respondents emphasize masculine values (as well as entrepreneurial ones) most. However, masculine values were attributed the least importance by our American respondents. This perhaps suggests that concern with achievement and money in a culture predicts the rise of capitalism. Then, masculine values may not be useful and functional any more for the affluent American nation, but may be so for the developing and transitionary Turkey.

However, our hypothesis regarding entrepreneurship values was not supported; Turkish respondents attributed more importance to those values than their American counterparts. The increased industrialization and developmental opportunities in Turkey after the 1980 s may be an explanation for this finding. About $80 \%$ of current business organizations were established after 1980 (Aycan and Fikret-Paşa, 2003); in the mid-1980s Turkey was among the fastest growing economies in the Organization for Economic Co-Operation and Development (OECD). Today Turkey continues to build a free-market economy and is considered one of the big emerging markets linking Europe, the Middle East and Central Asia. The younger private sector managers in Turkey are mostly graduates of American business schools and seem to be quite open to modern management techniques. In this environment rich in opportunities, our Turkish university students as potential private sector managers exposed to Western thinking may be more concerned with advancement, making decisions independently, being creative and helping one's organization get ahead.

Our results regarding gender differences in work values interestingly suggested that American women attributed greater importance to feminine values than American men, while Turkish men did the reverse. The greater importance attributed to feminine values by women than men in the U.S. is consistent with previous research which characterize women as socio-emotional, relationship and social oriented (Gilligan, 1982; Lau and Wong, 1992). Thus, in line with their relationship orientation, American women might value working with people in the workplace, serving their community and helping others. However, the greater endorsement of feminine values by Turkish men than women is interesting and merits some discussion. As will be 
remembered, in Hofstede's (1980) conceptualization, Turkish culture has been found to be high on the feminine side of the femininity-masculinity dimension. In the traditional socio-cultural Turkish context, people are expected to be human-oriented, to help others who are in difficult situations, to serve their community, and to be part of a team. Furthermore, Sargut (2001) in a study with Turkish university students found that feminine values (e.g., thoughtfulness, empathy, being loving toward children etc.) were attributed greater importance than masculine values by both genders. He concluded that even men emphasized those feminine values more than masculine values, as did women (although women tended to get slightly higher scores than men on feminine values). In the traditional Turkish context, maintaining the traditional value system might be expected from men. Thus, men's greater endorsement of feminine values may be an extension of these social and cultural expectations from men in the Turkish culture. On the other hand, women tend to show more individualistic concerns with increasing education and SES (Imamoğlu and Karakitapoğlu Aygün, 1999; Karakitapoğlu Aygün, 2004; Karakitapoğlu Aygün and Imamoğlu, 2002). They may tend to be more concerned with independence and autonomy than with social relationships. Of course, the above explanations are tentative and future studies are needed to shed light on these issues.

Another gender-related finding which deserves attention is the greater endorsement of entrepreneurship values by men in Turkey and by women in the U.S. The achievement and entrepreneurship orientation among Turkish men is consistent with the findings of previous research (Arda, 1993; Başaran, 1992; Elizur, 1994; Imamoğlu and Karakitapoğlu Aygün, 1999; Karakitapoğlu Aygün, 1996). Accordingly, men appear to be more concerned with respect, advancement, independence and creativity than women, which might have been resulted in greater preferences for entrepreneurship values on the part of men in the present study. However, the greater importance attributed to those values by American women than men are very interesting and inconsistent with traditional gender role expectations. Clearly, future studies are needed to further elaborate on this issue.
The PWE, contemporary work values and religiosity

One consistent finding across our cultural groups was the association of the PWE with entrepreneurship values. In both cultures, individuals who hold higher PWE beliefs seem to be oriented towards capitalism and free enterprise. Actually, supporting our results, in a study investigating the links between the PWE and vocational preferences, Furnham and Koritsas (1990) found that believers in the PWE preferred occupations and hard work values associated with entrepreneurial vocational interests. Not surprisingly, the entrepreneurial orientation emphasizing need for achievement and assuming personal responsibility for success and failure has some overlap with hard work dimension of the PWE.

Another consistent cross-cultural finding was the association between masculine values and the PWE in both cultural contexts. This finding is not surprising given the definition of the PWE, which includes the belief that hard work pays off in terms of success and getting ahead. In other words, believers in PWE seem to value instrumental components and tangible outcomes such as monetary gain (Sagie et al., 1996; Tang and Gilbert, 1995). Thus, hard work may be seen as necessary to produce desirable outcomes such as wealth, status, power and prestige.

The moderate but significant relationship between feminine values and the PWE in our Turkish sample is another interesting finding. It, once more, emphasizes the role of people-orientedness and social relationships in the Turkish culture. Consistent with the literature (Niles, 1994, 1999), our findings suggest that the meaning attributed to achievement and hard work may be different in the two cultures. For instance, in the individualistic American culture, achieving a goal and finding hard work fulfilling are ends in themselves, which emphasize competition and mastery (as shown by the significant correlation between the PWE and masculine values). However, in the collectivistic Turkish culture, achieving a goal and hard work may be instrumental in both serving selfinterest (as shown by the significant correlation between masculine values and the PWE) and group loyalty (as shown by the significant correlation between feminine values and the PWE). It should also be noted that masculine and feminine values were positively correlated with each other in our Turkish 
sample, but not in the U.S. sample. This interesting finding also supports our argument regarding the possible cross-cultural differences in the meaning of hard work/achievement and the co-existence of masculine and feminine attributes in a changing society such as Turkey. Future studies should elaborate on the real differences across cultures in work ethic and values, and the meaning attributed to these constructs in different cultures.

When we turn to the role of religiosity in the PWE, our findings illustrated that religiosity had an effect on PWE regardless of culture; highly religious participants reported greater PWE scores than less religious ones. Our findings support the Weberian idea that there is a relationship between religiosity and work-oriented behaviors. In Weber's thesis, the main motivator of capitalistic development is not exclusively theological but rather psychological. As Cox (1964) pointed out, Weber does not deal primarily with the elements of capitalist society and their peculiar organization, but with the capitalist spirit as it affects individuals within any society or nation whether predominantly Protestant or Catholic. His approach is, thus, essentially psychological. According to Weber's thesis, any religious belief system can produce 'the spirit of capitalism' if this belief system has the capability of rationalizing daily life and economic activities. Rationalization is the core of 'the spirit of capitalism' and the opposite of magical practices in a religious system. From a Weberian point of view, we can argue that after republican reforms in Turkey, the Turkish version of Islam rationalized daily life and encouraged a sort of 'the spirit of capitalism'.

Although Weber argued that Islamic societies do not support the spirit of capitalism because of the Islamic warrior ethic, other-world asceticism, and oriental despotism (Arslan, 2000), he did not say that Islam itself is an obstacle for the capitalistic development, but he felt that Islamic state organization was an obstacle. Our findings are not a threat to Weber's thesis, because Turkish society changed from a despotic oriental Islamic empire to a modern democratic industrial society. This process began as early as 1908 with early democratic reforms and Islamic other-world asceticism were transformed into a kind of this-world asceticism.

\section{Limitations and concluding remarks}

One of the limitations of the present study is that it is not a longitudinal research. In this study, we measured the university student's responses to our variables at one point in time. It would be an ideal design to follow those students and to see how they act as real managers in the future. The results would also provide a better understanding of the PWE and work values if student and working groups had been compared in each cultural context. Moreover, our results cannot be generalized to the Turkish and American societies at large since only student samples were used. The study is also limited in that it only examines two cultural groups, namely the U.S. and Turkey and thus provided limited information about the cross-cultural variability in the variables we measured. Future studies should examine those variables across other cultures, which have individualistic-collectivistic and/ or masculine-feminine characteristics (Hofstede, 1980; Triandis, 1995).

Our results concerning the PWE are also limited in the sense that we mostly included "hard work" items. In the literature, the PWE has been characterized as a multidimensional construct including different facets such as beliefs about asceticism, independence, time and leisure (Blau and Ryan, 1997; Furnham, 1990); the definition and the meaning attributed to the PWE may show variability in different cultural contexts. For example, Niles (1994; 1999) noted that Sri Lankan university students are similar to Australians, when work ethic is defined as a belief in hard work; however, when the PWE is defined as a need for mastery, Sri Lankans seem less committed than Australians. Clearly, there is a need to study different dimensions of the PWE cross-culturally. Finally, religiosity was measured by a single-item. Future studies should use multiple items to assure reliability and validity of this construct.

Despite these limitations, the study contributes to the literature in four ways:

1) It studies work values in two different cultural contexts. Certainly, Turkey as a predominantly Muslim culture, has been underrepresented and understudied in the literature; its unique history and socio-cultural 
characteristics make for interesting comparisons with other cultures.

2) By studying the link between the PWE and other contemporary work values, the present study provides a better understanding of the historical PWE characteristic and more modern work values in different cultural contexts. Our findings support the literature by confirming that the PWE includes masculine and entrepreneurship characteristics and this is robust across cultures. Our findings further suggest that, depending on the dominant sociocultural characteristics, the PWE may also be associated with feminine attributes, as it is in Turkey. This result supports our argument mentioned in the introduction that work values are socially and culturally determined.

3) By examining gender differences in both cultural contexts, the current study suggests that researchers should consider the interplay of culture and gender while investigating the PWE characteristics and other work values. Studying only cross-cultural or only gender-related differences may yield limited information since gender roles are embedded in socio-cultural characteristics. For instance, our results suggest that endorsement of the PWE changes according to the socio-cultural context (including both culture and gender) in which it was measured. Therefore, our results lend support to the notion that the PWE should be understood "as an issue which takes in the relationship between social attitudes and the socio-economic needs of the system, something which is an instrument of social control" (Niles, 1999; p. 856).

4) Last, but not least, by elucidating the role of religiosity in PWE, the current study sheds further light on the relationship between these two constructs, more than a century after Weber first put forward the idea. With a different perspective and considering individual-level perceptions of religiosity, our study supports his thesis that there is a relationship between religious beliefs and workoriented attitudes.

Our results have important implications for educational and business settings for the purposes of career planning, training and the fit between individual and organizational values. The results suggest students, workers and managers to understand, and clarify the role of one's work values. Recognizing one's value system is important for students in career planning to choose companies that match their values and; for workers in training and maximizing the alignment between individual and organizational goals. From the management perspective, we can suggest that managers should determine the work values (including the ethical ones) to be sought in their employees and select workers accordingly. Then, according to work values framework, they may establish an appropriate strategy for organizational socialization of newcomers (Dose, 1997). On the basis of the socio-cultural perspective that we adopted in the present study, one may claim that work values, especially the social consensus ones are more malleable and can be changed through socialization tactics to achieve maximum performance. Hence, it is possible for managers do design influential socialization techniques to increase individuals' adherence to organizational values. Our findings can also be used by agents who are making critical decisions in international businesses. Start-up and establishment of a business in a new culture require understanding the relative ordering of work beliefs, values and assumptions common in that particular culture.

\section{Notes}

1 Most of our students were from departments which are preparing potential managers, namely business, economics, political science and engineering.

2 We performed a multi-group confirmatory factor analysis to test the psychometric soundness and the metric invariance (invariance of factor loadings) of the PWE scale across two cultural contexts. We are grateful to an anonymous reviewer for encouraging us to focus more keenly on this issue. The results indicated that two items were not working well and had low factor loadings in the American sample. Therefore, we deleted those two items. The comparison of the first measurement model with 11 items and the final one with 9 items indicated a significant decrease in the chi-square, $\Delta \chi^{2}=139.53, \quad \Delta \mathrm{df}=34, \quad p<0.05, \quad$ suggesting an improvement in the model fit. This final 9-item one- 
factor measurement model revealed an acceptable fit, $\chi^{2}(54, N=466)=174.02, \chi^{2} / \mathrm{df}=3.22$, RMSEA $=$ 0.010 , GFI $=0.94$, CFI $=0.89$. Then, we put equality constraints on the factor loadings. Only one item (our society would have fewer problems if people had less leisure time) had different factor loadings in the two groups. Therefore, we released the equality constraint on that item. The difference between unconstrained and the constrained model was non-significant, $\Delta \chi^{2}=13.13, \Delta \mathrm{df}=8, p>0.05$. This result suggests that the PWE is overall defined by the same items across the two cultures.

3 As being similar to the PWE analyses, we performed a multi-group confirmatory factor analysis on work values scale. Three-factor measurement model revealed an acceptable fit, $\chi^{2}(375, \quad N=466)=$ $1049.59, \quad \chi^{2} / \mathrm{df}=2.8, \quad$ RMSEA $=0.09, \quad$ GFI $=0.83$, $\mathrm{CFI}=0.80$. Then, we put equality constraints on the factor loadings. Two items (working with the disadvantaged and working with honest people) had different factor loadings in the two groups. Therefore, those items were estimated freely in each group. The difference between unconstrained and the final constrained model was non-significant, $\Delta \chi^{2}=28.96, \quad \Delta \mathrm{df}=19$, $p>0.05$, suggesting (at least partial) invariance across cultures on the dimensions of work values.

4 We tested common method variance by using Harman's one factor test (Podsakoff et al., 2003; Podsakoff and Organ, 1986). We entered all the items in our variables of interest to a factor analysis. The analyses revealed similar results for both Turkish and American samples. For the American sample, nine factors emerged explaining $62.95 \%$ of the total variance. Explained variances were as follows for the nine factors: $17.83,12.06,8.01,5.42,4.79,4.16,4.01,3.43$, and 3.26. Similarly, for the Turkish sample eight factors emerged explaining $58.74 \%$ of the total variance. Explained variances were as follows: 18.30, 10.81, 8.40, $6.10,4.44,4.10,3.45$, and 3.14. Since no one single factor emerged in the analyses and the explained variances were somehow scattered around the multiple factors, the results suggest that common method variance is not a major problem in our data set.

5 In a previous analysis, gender differences were also explored. The results did not reveal any significant effects.

\section{References}

Aldemir, C., T. Arbak and Ö. N. T. Özmen: 2003, 'Türkiye'de İşgörme Anlayıșı Tanımı ve Boyutları (The Understanding of Working in Turkey, Its
Definition and Dimensions)', Yönetim Arass tırmalan Dergisi 3-1, 5-28.

Ali, A.: 1988, 'Scaling an Islamic Work Ethic', Journal of Social Psychology 128(5), 575-583.

Arda, B.: 1993, 'Tıp Öğrencilerinin Meslek Seçme Motivasyonları ve Değer Sistemleri Konusunda Bir Durum Değerlendirmesi (A Case Study on Motivational Factors in Selecting Professioan Among Medical Students and Their Value System)', in R. Bayraktar and I. Dağ (eds.), VII: Ulusal Psikoloji Kongresi (22-25 Eylül 1992) Bilimsel Çalı̧s malar El Kitab1, s. 59-65, Ankara.

Arslan, M.: 1999, 'A Cross-Cultural Comparison of the Work Ethic of Protestant Catholic and Muslim Managers', Unpublished Ph.D. Thesis, Leeds University.

Arslan, M.: 2000, 'A Cross-Cultural Comparison of British and Turkish Managers in Terms of Protestant Work Ethic Characteristics', Business Ethics: A European Review 9(1), 13-19.

Arslan, M.: 2001, 'The Work Ethic Values of Protestant British, Catholic Irish and Muslim Turkish Managers', Journal of Business Ethics 31, 321-339.

Atieh, M. J., A. P. Brief and D. A. Vollrath: 1987, 'The Protestant Work Ethic-Conservatism Paradox: Beliefs and Values in Work and Life', Personality and Individual Differences 8, 577-580.

Aycan, Z. and S. Fikret-Paşa: 2003, 'Career Choices, Job Selection Criteria, and Leadership Preferences in a Transitional Nation: The Case of Turkey', Journal of Career Development 30, 129-144.

Banks, R.: 1998, 'The Protestant Work Ethic', Faith in Business Quarterly 2(2), 5-7.

Başaran, F.: 1992, 'The University Students Value Preferences', Ankara Üniversitesi Dil ve Tarih Coğrafya Fakültesi Arass trrma Dergisi 14, 13-25.

Beit-Hallahmi, B.: 1979, 'Personal and Social Components of the Protestant Ethic', Journal of Social Psychology 109(2), 263-267.

Blau, G. and J. Ryan: 1997, 'On Measuring Work Ethic: A Neglected Work Commitment Facet', Journal of Vocational Behavior 51, 435-448.

Blum, U. and L. Dudley: 2001, 'Religion and Economic Growth, was Weber Right', Journal of Evolutionary, Economics 11, 207-230.

Chushmir, L. H. and C. S. Koberg: 1988, 'Religion and Attitudes Toward Work. A New Look at an Old Question', Journal of Organizational Behaviour 9(3), 251-262.

Cohen, J.: 1985, 'Protestant ethics and Status Attainment', Sociological Analysis 46, 49-58.

Cox, O.C.: 1964, Capitalism as a System (Monthly Review Press, New York), pp 57.

Demirutku, K.: 2000, 'Influence of Motivational Profile on Organizational Commitment and Job Satisfaction: 
A Cultural Exploration', Unpublished Master's Thesis. Middle East Technical University, Ankara.

De Mooij, M.: 1998, Global Marketing and Advertising (Sage, Thousand Oaks, CA).

Dose, J. J.: 1997, 'Work Values: An Integrative Framework and Illustrative Application to Organizational Socialization', Journal of Occupational and Organizational Psychology 70, 219-240.

Elizur, D.: 1994, 'Gender and Work Values: A Comparative Analysis', Journal of Social Psychology 134, 201-212.

Ergüder, Ü., Y. Esmer and E. Kalaycığlu: 1991, Türk Toplumunun Değerleri (Values of Turkish Society) (Türk Sanayicileri ve Issadamları Derneği, İstanbul).

Feather, N. T.: 1984, 'Protestant Ethic, Conservatism, and Values', Journal of Personality and Social Psychology 46, 1132-1141.

Feather, N. T.: 1998, 'Attitudes Toward High Achievers, Self-Esteem and Value Priorities for Australian, American and Canadian Students', Journal of CrossCultural Psychology 29, 749-759.

Furnham, A.: 1989, The Protestant Work Ethic: The Psychology of Work Beliefs and Values (Routledge, London).

Furnham, A.: 1990, 'A Content, Correlational and Factor Analytic Study of Seven Questionnaire Measures of the Protestant Work Ethic', Human Relations 43, 383-399.

Furnham, A.: 1991, 'The Protestant Work Ethic in Barbados', Journal of Social Psychology 131, 29-43.

Furnham, A. and C. Bland: 1983, 'The Protestant Work Ethic and Conservatism', Personality and Individual Differences 4(2), 205-206.

Furnham, A., M. Bond, P. Heaven and D. Hilton: 1993, 'A Comparison of Protestant Work Ethic Beliefs in Thirteen Nations', Journal of Social Psychology 133, 185-197.

Furnham, A. and E. Koritsas: 1990, 'The Protestant Work Ethic and Vocational Preference', Journal of Organizational Behavior 11, 43-45.

Furnham, A. and Muhiudeen: 1984, 'The Protestant Work Ethic in Britain and Malaysia', Journal of Social Psychology 122, 157-161.

Gilligan, C.: 1982, In a Different Voice: Psychological Theory and Women's Development (Harvard University Press, Cambridge, MA).

Henretta J. A.: 1991, The Origins of American Capitalism: Collected Essays (Northeastearn University Press).

Hoffman, L. W.: 1972, 'Early Childhood Experiences and Women's Achievement Motives', Journal of Social Issues 28, 129-155.

Hofstede, G.: 1980, Culture's Consequences: International Differences in Work Related Values (Sage, Beverly Hills, CA).

Hull, Bosley and Udell: 1985, 'Renewing the Hunt for the Heffalump: Identifying Potential Entrepreneurs by
Personality Characteristics', Journal of Small Business Management 22, 10-18.

Hyman, H. H., A. Payaslioğlu and F. W. Frey: 1958, 'The Values of Turkish College Youth', Public Opinion Quarterly 22, 275-291.

Imamoğlu, E. O. and Z. Karakitapoğlu Aygün: 1999, ‘1970’lerden 1990’lara Değerler: Üniversite Düzeyinde Gözlenen Zaman, Kuşak ve Cinsiyet Farklılıkları (Value Preferences From 1970s to 1990s: Cohort, Generation and Gender Differences at a Turkish University)', Turkish Journal of Psychology, 14(44), 1-22.

Jones, H. B.: 1997, 'The Protestant Ethic: Weber's Model and the Emprical Literature', Human Relations 50, 7.

Kağıtçıbaşı, Ç. (1977) Modernization and Values in Turkey. Paper Presented at the Panel on "Families and Women: Trends to Modernization and Change" (Eleventh annual meeting of Middle East Studies Association, New York).

Kağ1tçıbaş1, Ç.: 1986, 'Status of Women in Turkey: Cross-Cultural Perspectives', International Journal of Middle-East Studies 18(4), 485-499.

Karakitapoğlu Aygün, Z.: 1996, 'Contemporary Value Orientations of Adults and University Students', Master's Thesis. Middle East Technical University, Ankara.

Karakitapoğlu Aygün, Z. and E. O. Imamoğlu: 2002, 'Value Domains of Turkish Adults and University Students', The Journal of Social Psychology 142, 333-351.

Karakitapoğlu Aygün, Z.: 2004, 'Self, Identity, and Emotional Well-Being Among Turkish University Students', The Journal of Psychology 138(5), 457-478.

Kim, H.: 1977, 'The Relationship of Protestant Ethic Beliefs and Values of Achievement', Journal for the Scientific Study of Religion 16, 255-262.

Lau, S. and A. K. Wong: 1992, 'Value and Sex-Role Orientation of Chinese Adolescents', International Journal of Psychology 27, 3-17.

Lodge, G.: 1975, The New American Ideology (Alfred Knopf, New York).

Lynn, R.: 1993, 'Sex Differences in Competitiveness and Valuation of Money in Twenty Countries', Journal of Social Psychology 133, 507-511.

Ma, L. C.: 1986, 'The Protestant Ethic Among Taiwanese College Students', Journal of Psychology 120, 219-224.

Mayer, A. and H. Sharp: 1962, 'Religious Preference and Worldly Success', American Sociological Review 27, 220227.

McClelland, D.: 1961, The Achieving Society (D Van Nostrand Company, Princeton, New Jersey).

McGrath, MacMillan, Yang and Tsai: 1992, 'Does Culture Endure, or is it Malleable? Issues for Entrepreneurial Economic Development', Journal of Business Venturing 7, 441-458. 
Mirels, H. L. and J. B. Garrett: 1971, 'The Protestant Ethic as a Personality Variable', Journal of Consulting and Clinical Psychology 36(1), 40-44.

Niles, F. S.: 1994, 'The Work Ethic in Australia and SriLanka', Journal of Social Psychology 134(1), 55-59.

Niles, F. S.: 1999, 'Toward a Cross-Cultural Understanding of Work-Related Beliefs', Human Relations 52(7), 855-867.

Phalet, K. and W. Claeys: 1993, 'A Comparative Study of Turkish and Belgian youth', Journal of Cross-Cultural Psychology 24(3), 319-343.

Örücü, E., T. Asunakutlu, and G. Öncü: 2003, 'Çalışanların İş Değerleri ve Bir Uygulama (Work Values of Employees and a Field Study)', İktisat, İsletme ve Finans: $\dot{I}$ nceleme-Aras t1rma, 3-17.

Podsakoff, P. M., S. B. MacKenzie, J. Y. Lee and N. P. Podsakoff: 2003, 'Common Method Biases in Behavioral Research: A Critical Review of the Literature and Recommended Remedies', Journal of Applied Psychology 88, 879-903.

Podsakoff, P. and D. Organ: 1986, 'Self-Reports in Organizational Research: Problems and Prospects', Journal of Management 12, 69-82.

Pratto, F., L. M. Stallworth, J. Sidanius and B. Siers: 1997, 'The Gender Gap in Occupational Role Attainment: A Social Dominance Approach', Journal of Personality and Social Psychology 72, 37-53.

Ray, J. J.: 1982, 'The Protestant Ethic in Australia', Journal of Social Psychology 116(1), 127-138.

Roos, L. L. and N. Roos: 1971, Managers of Modernization: Organization and Elites in Turkey (1950-1969) (Harvard University, Massachutes).

Sagie, A., D. Elizur and M. Koslowsky: 1996, 'Work Values: A Theoretical Overview and a Model of Their Effects', Journal of Organizational Behavior 17, 503-514.

Sargut, A. S.: 2001, Kültürleraras1 Farklıląs ma ve Yönetim (Cross-cultural Differentiation and Management) (Imge kitabevi, Ankara).

Sombart, W.: 1913, The Jews and Modern Capitalism (T.F. Unwin, London).

Spence, J.: 1985, 'Achievement American Styles: The Rewards and Costs of Individualism', American Psychologist 40, 1285-1295.

Super, D. E.: 1973, 'The Work Values Inventory', in D. G. Zytowski (ed.), Contemporary Approaches to Interest Measurement (University of Minnesota Press, Minneapolis, MN), pp. 189-205.

Tang, T. L. P.: 1989, 'Effects of Work Ethic and Task Lables on Task Preference', Journal of Psychology 123, 429-438.
Tang, T. L. P. and P. R. Gilbert: 1995, 'Attitudes Toward Money as Related to Intrinsic and Extrinsic Job Satisfaction, Stress and Work-Related Attitudes', Personality and Individual Differences 19, 327-332.

Tang, T. L. P. and J. Y. Tzeng: 1992, 'Demographic Correlates of the Protestant Work Ethic', The Journal of Psychology 126(2), 164.

Thomas, A. S. and S. Mueller: 1998, 'Are Entrepreneurs The Same Across Cultures?’, USASBE Annual National Conference, 15-18 January.

Tınaz, P.: 1996, 'Çalışanların İş Değerleri Konusunda Bir Durum Değerlendirmesi (A Case Study on Work Values of Employees)', Amme İdaresi Dergisi 29, 43-53.

Triandis, H. C.: 1995, Individualism and Collectivism (Westview, Boulder).

Ülgener, S. F.: 1981, Iktisadi Cozulmenin Ahlak ve Zihniyet Dunyasi, (The Ethos and the Ideology of the Economic Decay) (Der Yayınları, Istanbul).

Wayne, E. S.: 1989, 'An Instrument to Measure Adherence to the Protestant Ehic and Contemporary Work Values', Journal of Business Ethics 8, 793804.

Weber, M.: 1985, Protestan Ahlakı ve Kapitalizm Ruhu, (The Protestant Ethic and the Spirit of Capitalism) (Hil Yayın, İstanbul).

Wentworth, D. K. and R. M. Chell: 1997, 'American College Students and the Protestant Work Ethic', The Journal of Social Psychology 137(3), 284-296.

Wickham, P. A.: 2003, Strategic Entrepeneurship, Financial Times/Pearson Education.

Zahide Karakitapoğlu Aygün Faculty of Business Administration, Bilkent University, 06800 Ankara, Turkey

E-mail: zkaygun@bilkent.edu.tr

Mahmut Arslan Department of Business Administration, Hacettepe University, 06520 Ankara, Turkey E-mail:marslan@hacettepe.edu.tr

Salih Güney

Turkish Military Academy, 06654 Ankara, Turkey E-mail:saguney@yahoo.com 